Article

\title{
Reading the Book of Nature after Nature
}

\author{
Jacob Holsinger Sherman
}

Department of Philosophy and Religion, California Institute of Integral Studies, San Francisco, CA 94103, USA; jsherman@ciis.edu

Received: 10 March 2020; Accepted: 16 April 2020; Published: 20 April 2020

check for updates

\begin{abstract}
Early modernity tended to appeal to the trope of the book of nature as a way of securing knowledge—including knowledge about God—against the exigencies of history and culture, but as theorists such as Timothy Morton, Bruno Latour, and others have argued, today this assumed dualism of nature and culture is both ecologically and critically suspect. What might it mean to read the book of nature in a time of ecological precarity, what many have called the Anthropocene? I will argue that premodern theological traditions of the book of nature, such as one finds in the twelfth century Hugh of Saint Victor, have something extremely important to add to a postmodern 'terrestrial' hermeneutics of nature, precisely because the premodern book of nature already performs the construal of nature as culture (and of culture as nature) so often recommended today by critics such as Latour, Haraway, and others. On such an account, nature is neither a fantasy object to be ignored or fled, nor a stable text to be tamed, rationalized, and epistemically leveraged, but rather the changing concept and experience of nature is a symbol illuminated in a book we half receive, and half create, a symbol open to both critique and contemplation, which gives rise to thought, action, and the sort of novel moral intuitions we need now more than ever.
\end{abstract}

Keywords: Book of Nature; Hugh of Saint Victor; Anthropocene; Bruno Latour; Timothy Morton; Slavoj Žižek; ecology and religion; eco-theology

\section{Introduction}

As we confront the advent of the state of universalized precarity and massive global changes entailed by "the new climatic regime," as Bruno Latour calls it, the vulnerability of our practices, traditions, and the human condition itself become ever more apparent (Latour 2018). How do we respond to challenges of such scope? More to the point of this Special Issue on 'Faith, Vulnerability, and the Anthropocene,' we might ask: are there resources within the intellectual and spiritual traditions of communities of faith that can help us in the collective effort to discover the moral sources required to meet the unprecedented tests of our time?

To many, it might seem absurd to suggest that the humanities, let alone philosophy or theology, could have anything to say about such an intractably material situation as the contemporary ecological crisis; surely, only science can save us now? And yet, one can argue, that our predicament is not only a technical and scientific crisis, but also a crisis of human collective activity, which is to say, of politics, and so depends crucially upon human commitment, imagination, and deliberation (Arendt 1998). The paradox of the Anthropocene is this: human agency is now responsible for fundamentally transforming the biogeochemistry of the earth, while at the same time, we seem incapable of altering the shape of our collective activities. We are tragically responsible, and we can't seem to do anything about it.

But might this paradox seem intractable only because basic ontological, ethical and aesthetic assumptions have gone unquestioned? And, if so, doesn't this cry out for a metaphysical and theological response? 
One of the most important of these often-elided questions is the relationship between human beings and nature, a relationship that was once taken for granted, but that now appears deeply unstable in the epoch of the 'Anthropocene'. Early modern philosophy taught us to appeal to nature as a source of certainty and universality, an epistemological bulwark against the exigencies of history and culture, but today this assumed dualism of nature and culture is both ecologically and critically suspect. There is moral risk here, for 'nature' seems to have been the constitutive good in relationship to which so many of the novel moral intuitions and practices of our ecological consciousness came into being. ${ }^{1}$ Can we still appeal to nature, and what might that appeal look like in a time of ecological precarity? In order to address such concerns, this essay begins by critically considering the contemporary scholarly questioning of the very concept of nature, and then argues that the creative retrieval of premodern theological traditions of the book of nature might provide key tools for the construction of the kind of postmodern 'terrestrial' hermeneutics of nature we need now more than ever.

\section{The Problem of 'Nature'}

What's the matter with Nature? One way to think about it would be as follows. Ever since the nineteenth century, environmental and ecological ethics have tended to appeal to a unified concept of nature as a given, well-ordered, moral and biophysical whole that must be saved, managed or preserved. Formally, this peculiarly modern understanding trades on a disjunctive theory of nature as wilderness: the wilderness or the wild is all that is other from culture. Materially, such appeals are seen at work in strategies which aim to draw boundaries between nature and the human in order to create a preserve or protected space from the influence of human technology and culture-making. Today, however, this idea of nature as corrupted by the supplement of culture is increasingly contested.

To begin with, the unified modernist concept of nature has been thrown into question by research in the history, sociology, and philosophy of science (Latour 1993, 2004; Stengers 2010; Grebowicz et al. 2013; Haraway 2016a, 2016b). We can take Bruno Latour as representative here. According to Latour, the critique of nature is bound up with a critique of modernity. On Latour's account, modernity defines itself by erecting an absolute dualism between nature and society, an establishment accomplished by the elevation of the human subject out of nature and into the putatively transcendent realm of culture. We are, I assume, all familiar with accounts of modernity that make this sort of Cartesian or Kantian dualism central to the identity of the modern. What Latour adds to this common story, however, is a strong account of how this modern aspiration to purify the realms of nature and culture both came about, and how it has always been undone by the equally modern aspiration to 'illicitly' mix these two realms. Thus, modernity is marked not by one but by two fundamentally conflicting practices that Latour calls 'purification' and 'translation' (Latour 1993, pp. 8-12). In purification, moderns seek through experimental and analytic means to construct a nature freed from culture and subjectivity, while in translation (or 'hybridization') moderns bring together these supposedly pure spheres in new hybrid assemblages of nature and culture (Latour 1993, pp. 39-48).

Hybrids, however, remain invisible to modern eyes. Modernity understands itself only in terms of the first procedure of purification. This is the story we were all taught. Modernity purifies the world; it separates the value spheres of the good, the true, and the beautiful, and so frees the world from antique superstition. The earth no longer groans, trees no longer speak, and the heavens dictate neither our moods nor the proper construction of the republic. Nature exists in its pure brute calculability, mute,

1 The vocabulary here is Charles Taylor's. Taylor distinguishes between 'constitutive goods' and 'life goods'. A “constitutive good is a moral source ... that is, it is a something the love of which empowers us to do and be good" (Taylor 1989, p. 93). Life goods, by contrast, are things it is good to be, what are often called virtues. But these life goods are goods precisely because of their relationship to some substantive aspect of reality, the constitutive good, relation to which constitutes the goodness of life goods and empowers the agent in his or her moral actions. Although a genealogical account of how we came to see environmental questions as ethical and not merely pragmatic is beyond my scope here, one can argue that 'Nature' often played a key role as the constitutive good in the emergence of ecological virtues throughout the nineteenth and twentieth centuries. 
stupid, and subject to the laws of mechanical necessity. With nature scoured of any human or personal trace, a new Promethean humanity discovers (or invents) itself as utterly free from the constraints of nature. What it means to be modern is to distill finally culture from nature, the discursive from the real, the social, linguistic, and constructed from the natural, material, and given. As one of Latour's interpreters explains, "Modernity tries to purify the world by dissecting it into two utterly opposed realms. On one side we have the human sphere, composed of transparent freedom and ruled by arbitrary and incommensurable perspectives. On the other side we have nature or the external world, made up of hard matters of fact and acting with objective, mechanical precision" (Harman 2009, p. 57).

The error of premodern peoples, so the story goes, was to believe in a seamless fabric of nature and culture: political arrangements were believed not only to model but also to follow the heavens, signatures were spread throughout the world of nature, the moon somehow connected to the growing of seeds or to the metal silver, the sun for its part sympathetic to gold, our own bodies and moods composed of the four elements that make up our temperaments ... a world of cosmos, psyche and politeia all mixed, confused. But moderns, it is said, put to an end this confusion. "[They] have cut the Gordian knot with a well-honed sword. The shaft is broken: on the left, they have put knowledge of things; on the right, power and human politics" (Latour 1993, p. 3).

As Latour develops his account, he shows that the modern process of purification is a bit more complex still. Modernity separates-horizontally as it were-nature from culture, but it also vertically separates nature and culture from God, divinity, and the spiritual realm, a God that is now crossed-out because incapable of ever appearing within a world entirely divided between nature and culture. Latour writes, "Modernity arises first from the conjoined creation of these three entities [exclusive humanity, nonhuman nature, and the crossed-out God], and then from the masking of the conjoined birth and the separate treatment of the three communities while, underneath, hybrid continue to multiply as an effect of this separate treatment" (Latour 1993, p. 13). For the modernizers, if God is allowed to be anywhere, it's in the interiority of mind and soul, but never in the land, the laws, or the economy. Modernity is premised upon a double-process of separation: humans from nonhumans and above from below.

Of course, Latour insists that we have never in fact been modern, in the sense that we have never succeeded - could never succeed-in finally purifying nature and culture, but this leads to the worry that perhaps neither have we ever known nature. The very concept of nature may be a will-of-the-wisp.

This account becomes even more powerful when read alongside the great transformations to Earth systems that provide the theme for this Special Issue. The growing awareness that human influence is now so ubiquitous upon the surface of the earth that strictly speaking 'untrammelled nature' no longer exists has led an increasing number of scientists, scholars, and activists to speak of the Anthropocene. ${ }^{2}$ As the ultimate instance of hybridization, climate change exposes the unsustainability of the modern bifurcation of nature and culture and casts both poles of this bifurcated reality under a cloud of critical suspicion.

According to the philosopher Slavoj Žižek, the situation is even more extreme than this. It is not only that humanity has become a ubiquitous presence and geological force, altering earth systems that will be catastrophic for many, but also that we have reached into the previously hidden depths of nature and, as it were, taken control. As Žižek writes: "the main consequence of the scientific breakthroughs in biogenetics is the end of nature. Once we know the rules of its construction, natural

2 Defining even what the Anthropocene means is controversial. Whatever else it means, it refers to the enormous influence of human beings upon the entire terrestrial system (Lewis and Maslin 2018). As is now well known, human activity has increasingly displaced the more-than-human world to the point that we have left such a mark and our presence has grown so ubiquitous that we are now rightly described as a geological agent. Use of the term in this context is credited to the Dutch atmospheric chemist, Paul Crutzen, who claimed that the human, the Anthropos, had become such a "geoforce" that we were no longer living in the Holocene but rather in the Anthropocene (Crutzen 2006). As the popularity of the term has grown, so too has scholarly recognition of the theoretical, philosophical and theological challenges it poses (Hamilton et al. 2015; Deane-Drummond et al. 2017). 
organisms are transformed into objects amenable to manipulation ... . nature is no longer "natural," the reliable "dense" background of our lives; it now appears as a fragile mechanism which, at any point, can explode in a catastrophic manner" (Žižek 2008a, p. 435). For Žižek, the paradigm case of this is biogenetics, which reduces the human psyche itself to an object of manipulation. "By reducing [the human] to just another natural object whose properties can be manipulated," writes Žižek, "what we lose is not (only) humanity but nature itself" (Žižek 2008a, p. 435).

Žižek is not the first to note this. Already in the middle of the last century, C. S. Lewis had argued something similar. In The Abolition of Man, Lewis argued that "we reduce things to mere Nature in order that we may 'conquer' them. We are always conquering Nature, because 'Nature' is the name for what we have, to some extent, conquered. The price of conquest is to treat a thing as mere Nature. Every conquest over Nature increases her domain. The stars do not become Nature till we can weigh and measure them: the soul does not become Nature till we can psychoanalyse her" (Lewis 2001, p. 43).

With the horrors of National Socialism in mind, Lewis imagined that the end point of this process would finally be the conquering of the human itself, the abolition of man, for once we reduce our species to mere nature, we lose both nature and humanity. By reducing nature to a story of particles and their relations, or to atomic forces and nomological regularities, and so by removing from the world its dynamic, vital, ensouled meaning, we 'discover' ourselves in a vast material machine subject either to mechanical or stochastic laws rather than in a cosmos replete with inescapable meaning. But having discovered that we dwell in such a universe, we eventually discover that the body too is subject to these very modes of mechanical understanding, at which point the life of the body becomes essentially unintelligible, and we begin to suspect that we ourselves are nothing but anticipatory corpses (Bishop 2011). Finally, we turn the analysis back on the very consciousness doing the analyzing and we dissolve ourselves into the pulverized bits of universe to which we've reduced everything else.

But where Lewis laments this final magician's bargain-give up our soul, get power in return-Žižek welcomes it in the name of an ecology without nature: "The ultimate obstacle to protecting nature is the very notion of nature we rely on" (Žižek 2008a, p. 435). The posthuman future that modern science and technology have inaugurated is thus rather ironically dubbed the Anthropocene, but for Žižek it conclusively demonstrates the falseness of the old picture of nature, the picture that held us captive when we still also believed in humanity.

Žižek's conclusions have been significantly bolstered by certain strands of literary ecocriticism, which have increasingly demonstrated that concepts of nature in foundational ecological texts are geographically particular, socially contingent, imaginative and even theological. ${ }^{3}$ In place of the unified book of nature invoked both by classical environmentalists and early modern scientists, the ecocritics point instead to an array of constructed natures, each imaginatively apprehending and evaluating reality in different ways.

Timothy Morton, for instance, argues that our ongoing appeal to the idea of nature is vitiating our ecological politics. As he writes: “The idea of 'nature' ... will have to wither away in an 'ecological' state of human society. Strange as it may sound, the idea of nature is getting in the way of properly ecological forms of culture, philosophy, politics, and art." (Morton 2007, p. 1).

Morton argues that, hitherto, ecocriticism has engaged in too much advocacy and too little criticism. Instead of cheering for nature, it ought to be destabilizing the very concept-even refusing to reinvent the concept:

When I suggest that we drop the concept of nature, I am saying that we really drop it, rather than try to come up with hastily conceived, 'new and improved' solutions.... 'Ecology

3 On the contested meanings of the word 'nature' see (Gersdorf and Mayer 2006; Clark 2011; Lewis 1960; Collingwood 1945; Williams 2014; Hadot 2006; Williams 1980; Latour 1993; Evernden 1992; Rolston 1997; Whitehead 2015; Morton 2013b). For a sampling of religious and theological responses to this conceptual diversity, see (Kaufman 1972; Albertson and King 2010; McGrath 2001). 
without nature' is a relentless questioning of essence, rather than some special new thing .... (Morton 2007, p. 21)

If we relentlessly question nature, we find that it disappears; and in its place-as Collingwood observed-all that is left is history and change (Collingwood 1945). The concept of nature elides this impermanence from our view and provides the illusion of a stable ahistorical ground upon which human culture and history take their privileged place.

The concept of nature that Morton and Žižek primarily target stems from literary innovations canonized in the Romantic Movement of the 18th and early 19th centuries, which, Morton argues, still shape our ecological imaginary: they taught us to believe that a view of things-especially a view of nature-could change the world: "Nature," Morton writes, "is the reduction of nonhuman beings to their aesthetic appearance for humans" (Morton 2013b, p. 311). It's a spectatorial project. Romanticism, the aesthetic parent of nature writing and nature poetry, is the parent of contemporary ecological consciousness, to be sure, but on Morton's account it is an abusive parent, for while the Romantic view of nature sets our hearts aflutter, its aestheticism stops us thinking and spoils our politics. By taking leave of it, they take leave as well of the naive summer-of-love ecospirituality that influenced so much of the previous decades' popular environmentalism in general, and discussions of religion and ecology in particular.

At this point, many of us who have learned from the Romantics and the nature writing tradition will want to register our doubt. ${ }^{4}$ Contemporary critiques of Romanticism tend to accuse it of opposite vices: both of rendering nature too other as 'the wild' and yet of covertly taming nature by subjecting it to an even more powerful aesthetic anthropocentrism. This aporetic doubling of Romanticism's infractions may in fact apply to some in the canon, but not to thinkers like Wordsworth, Coleridge, or, for that matter, Annie Dillard. These poetic thinkers justified and acknowledged a certain anthropocentrism not through a transcendental elevation of the subject alone, but rather by including the human alongside all regarded creatures as bound within a single divine creation.

Latour also thinks that our concept of nature is spoiling our politics, but for him the primary culprit is less the nature of early modern romanticism than the nature of early modern science. Ever since Galileo, we have increasingly acted as if the only true account of nature were one that could be rendered in the mathematics applicable to the physics of falling bodies, that is to say, a view of the Earth from outside, outside our ecological niches, outside our bodies, outside of subjectivity itself. After all, it was Galileo who insisted in The Assayer:

Philosophy is written in this grand book-I mean the universe-which stands continually open to our gaze, but it cannot be understood unless one first learns to comprehend the language and interpret the characters in which it is written. It is written in the language of mathematics, and its characters are triangles, circles, and other geometrical figures, without which it is humanly impossible to comprehend a single word of it ... without these, one wanders about in a dark labyrinth. ... nature takes no delight in poetry. (Galilei and Drake 1990)

Nature comes to mean just what can be measured with our rulers and clocks, what can be calculated, and nothing more. Latour calls this a 'sadistic asceticism' through which we trained ourselves to

4 Morton allows that the nineteenth century poets were richer and more nuanced than the popular nature movements they helped to fuel. Here, we might distinguish the term Romantic, as a kind of cultural sensibility, from the Romantics, that is, the authors, poets, and artists themselves. The reception history of the Romantics may give rise to the naïve 'Romantic' traditions of nature about which Morton is so critical. Nevertheless, in his more recent works, Morton allows that the Romantics themselves were more lucid than this: "It's just not correct to think of them as naive nature writers, as we too often do, even though they did tell stories about encountering mountains or hearing the terrifying yet invigorating sound of the surf. In fact, they were trying to get past all that pretty nature stuff, which was old by the time they started ... . [The British Romantics'] approach suggests a less anthropocentric attitude, and one that was in fact more in line with scientific curiosity; they were laying bare how their stance changed what they were seeing" (Morton 2018, pp. 143-44). 
acknowledge as real only that which obeys the grammar of number and mechanism. "Hence," he writes, "the classic division between knowledge seen from afar but assured, and imagination, which saw things up close but without grounding in reality: at worst, simple fairy tales, at best, ancient myths, respectable but without verifiable content" (Latour 2018, p. 69).

Why has the modern ecology movement been so singularly unsuccessful in mobilizing the political and social action needed to meet the challenge of massive disruptions of earth systems? Because a reified concept of nature as the other of culture also rends asunder metaphysics and morality, positive knowledge and religious feeling, thus leaving us bereft of moral categories adequate to the integral complex of nature and culture that constitutes climate change.

From Morton to Žižek to Latour, all agree that the concept of nature has become unsustainable. But what do they offer in its place? On the one hand, in the name of getting rid of nature, Žižek and Morton return us to something like naturalism in its starkest form; the world may be stranger, more magical or more monstrous than run-of-the-mill naturalism allows, but, nevertheless, for both authors the radical alterity of nature becomes a deromanticized wilderness, the desert of the real (Žižek 2008b). Nothing ever actually touches anything else: indeed, in at least one of his moods, Morton commends a kind of chastened Cartesianism claiming that what we ought to adopt is a substance-less Cartesian dualism (Morton 2013b). Subjects are subjects irreducibly related to the horrifyingly brute vacuous actuality of others, the strange strangers that surround them. If communication is possible across so great a divide, it can only be a kind of unmediated, inexplicable communication-a nihilistic occasionalism, a realist magic (Morton 2013a). But such an ontological wilderness, because it offers no genuine communion, and is in its depths unreachable, is ironically just the kind of wilderness that makes itself available for human exploitation. Without the poetry, and in lieu of any human access to the alien reality of natural things, it would seem that all we can act upon are the deliverances of scientific reason and the demands of rational politics. There is no extra-linguistic whole which might bestow a value beyond the political or economic upon creatures.

For his part, Latour insists by contrast that relationship takes absolute priority over both the parts and the whole, but this has problems of its own. On the one hand, if parts are never themselves save through their exhaustive constitution by dynamic relations, then every individual—every actor, every agent-is infinitesimally composed of relations to other agents who only are through their infinite relations, each simultaneously formed and transformed, like Actaeon, only to be torn apart by its changing relations to every other. On the other hand, even relations themselves seem to dissolve if there is no whole transcending these relations, for movement and change are only possible if some substantial identity transcends such change-in the absence of this wholeness, there is only replacement, which, when universalized, is indistinguishable from stasis.

\section{Retrieving the Book of Nature}

"Nature," writes Holmes Rolston, "is perhaps the most ancient philosophical category, yet few others are of greater current relevance" (Rolston 1986, p. 9). Nevertheless, those seeking an ecology without nature insist that the concept of nature, in its vague, constantly renegotiated identity, is just a series of contingent metaphors and that the business of careful political ecology can dispense with these. I am inclined to agree that nature is a metaphor, one that is shot through with contingency and historicity. But I want to be cautious about dispensing with it. For one thing, as Pierre Hadot writes, "a metaphor is never innocent. It is the vehicle of an entire set of images, feelings, and inner dispositions, which have an unconscious influence on consciousness" (Hadot 2006, p. 76). If the morally novel developments of, say, the environmental movement have been mediated to us through the metaphor or symbol of nature, we should be cautious about dispensing with that symbol too quickly. In his Poetics, Aristotle notes that there can be no ethos without a mythos. ${ }^{5}$ If we relinquish the 
symbol of nature, even in the name of radical ecology, we may find our meta-ethical grounds disappear along with it.

But if we are attentive to the contingencies of history and culture, to the functioning of ideology, and projection, how can we continue to make ethical appeals to nature without bad faith?

Here, I think, the theological tradition of the book of nature has something extremely important to add. As I have intimated already, early modernity tended to appeal to the trope of the book of nature as a way of securing knowledge-including knowledge about God-against the exigencies of history and culture. For modern natural philosophers, the book of nature provided a hidden but trustworthy script—one that could be read identically so long as certain procedures were followed—and that thus provided the necessary foundations for modern science. For early modern theologians, the book of nature played an equally foundational role. Following the late-medieval Raymond of Sabunde's The Book of Nature or Creatures [Liber naturae sive creaturarum], so-called natural theology was called upon to stand in the skeptical breach providing certainty, apodicticity, and a set of evidences for religion unrelated to the presuppositions of faith (Harrison 2015, p. 73; Wolterstorff 2010).

This was a reading of precisely the sort of nature against which Latour and others have rightly raised a critique, but until its early modern transposition into the language of mathematics, the theological trope of the book of nature operated quite differently. Indeed, for more than a millennia, the liber naturae tradition constituted a vision of nature not as a bulwark against contingency but as ineluctably hermeneutical, susceptible to being known in positive ways, to be sure, but irreducible to any particular exegesis of its being.

This premodern tradition of the book of nature envisions a co-constitutive relationship between humanity and nature that already performs the construal of nature as culture (and of culture as nature) so often recommended today. In this regard, premodern theological traditions of the book of nature may provide resources for the construction of a postmodern 'terrestrial' hermeneutics of nature, a reading of nature that recognizes its agency alongside and within our own. ${ }^{6}$ For if Creation is the divine work, the product of the divine 'culture', then it cannot be poor in meaning compared with our human products; indeed, it must be saturated with a deeper, partly hidden meaning.

With origins in antiquity, especially with Augustine, the metaphor of the book of nature came to prominence in that alter-Augustinus, Hugh of St Victor, during the so-called twelfth-century rediscovery of nature (Angelici 2020; Cizewski 1987; Coolman 2010; Falque 2017; Chenu [1957] 1997; Illich 1993). For Hugh, the motif points to an equally spiritual and hermeneutical approach to the 'reading' of creation, taken to be inseparable from the community's concomitant reading of scripture (Falque 2017). If creation is itself a book, analogous to the book of scripture, then our relationship with creation is one that resists in advance both modern pretensions to the mastery, and possession of nature, and the prevalence of any ultimate nature/culture duality. Instead, our reading of nature, as our reading of scripture, can only be undertaken through a kind of contemplative theological comportment, a specific way of life informed by communal practices whose ultimate shape is Christological and whose ultimate aim is doxological.

As Hugh writes in his meditation, De Tribus Diebus 4.3, "For this whole sensible world is a kind of book written by the finger of God, that is, created by divine power, and each creature is a kind of figure, not invented by human determination, but established by the divine will to manifest and in some way signify the invisible wisdom of God" (Coolman and Coulter 2010, p. 63).

Despite the reference to Romans 1:20, Hugh doesn't deploy natural theology in the way that modern readers of the book of nature would, in the service of the proofs for the existence of God. Rather, he insists that the book of nature be wedded to a kind of paideia, a cultivation of the 'art of reading' [ordo legendi] which corresponds equally to an 'art of living' [ordo vivendi]:

6 On the notion of the 'terrestrial, see (Latour 2018, pp. 40-42). 
Just as when an unlettered person sees an open book and notices the shapes but does not recognize the letters, so ... people who are not aware of the things of God see on the outside the beauty in these visible creatures, but they do not understand its meaning. (Coolman and Coulter 2010, p. 63)

How are we to be made capable of understanding this meaning? We must allow ourselves to be opened, to be shaped, and formed to become other. Characteristically for Hugh, as earlier for Augustine, to be formed means to be taught how to read, to attend to the other, and for this purpose God sent yet another book. As Hugh explains in De Sacramentis (1.6.5), "Wisdom was a book written within; the work of wisdom [that is, creation] a book written without." But human sin has darkened our eyes to these books, so God sent another volume, one that not only signifies but illumines: the book of the Incarnation of the Son of God.

He assumed flesh not losing divinity, and was placed as a book written within and without; in humanity without, within in divinity, so that it might be read without through imitation, within through contemplation .... (Hugh of Saint-Victor 2007).

The intertextual Christological tearing of the veil between nature and culture couldn't be more pronounced. Books are, of course, synecdoches for culture, but as Hugh's remarkable treatise on reading, the Didascalicon, makes clear, in this twelfth-century context books abound in the most surprising of places: Scripture, to be sure, but also nature, the world, the arts of hunting, cooking, farming, our bodies themselves, and the incarnate body of Christ-all are available to be read (Hugh of Saint-Victor 1991). Moreover, they are read in unexpected ways that include the whole pattern of our ethical lives (reading as imitation) and the most elevated ascent of our minds (reading as contemplation). The historical event of the incarnation and the ways of life-the ecclesia-to which it gives rise train and empower the believer not only to interpret scripture, but also nature, and indeed his or her own life, for, in this way, one's life itself also becomes a book written by the finger of God.

\section{Conclusions}

The ontological implications of this are profound. As Latour has argued, once we dispense with a demarcation of nature and culture, human freedom, culture, and imagination must themselves be seen to participate in nature-rather than modernist self-transparency, we discover a kind of wildness within our very selves and cultures, which displays the same opacity as nature without. Nature is the otherness that surrounds us, and the otherness that indwells us (Latour 1993).

If the universe is not bifurcated into active agents of meaning, on the one hand, and stubborn facts, on the other, then at least two strategies of approaching the universe open to view. Either, we might see meaning itself as fundamentally illusory, the sort of thing that dissolves once we rid ourselves of the illusions of our own superiority. Or, we might alternatively see wisdom and intelligibility as ontologically basic, and so expect to find the world itself replete with a plenitude of meaning and agency. In this respect, the best of Romantic 'anthropomorphising' is saved. It is not a lapse into the pathetic fallacy that lilies have feelings like ours, but a repetition of nature's hidden significance which involves simultaneously the 'naturalising' of our own human responses. The lily imbued with our response is also our response imbued with the entrancing strangeness of the lily.

On such an account, we might expect to find within our own active capacities a kind of participation in, or expression of the ubiquitous meaning-making of the universe. This is not an expression of anthropocentric artistic arrogance: instead, in order to mean in some respects beyond the lily, we must first attend to its own utterances. Only with such vulnerable communion does a reading of the book of nature become also legitimately our own continued writing of it. This is what we find in Hugh's account, and so much of the theological tradition alongside him: nature not as a concept but as a symbol, not only the symbol of divinity, but finally the symbol of the union of God and creation in the man Jesus Christ, the Logos-Wisdom through whom all things were made and who on earth 
could speak the word that turned water into wine, restored damaged natures, and caused the dead to live again.

Nature as creation, participating in and suspended from the Triune God, functions as the value-bestowing constitutive good that we found wanting in contemporary accounts of ecology without nature. But it has this capacity not as a substance among other substances, nor a thing existing alongside of and in contrast to other things of the world, but precisely as a symbol. A symbol is, of course, a sign, but a sign that partakes synechdochically of that which it signifies. This is what distinguishes it from a mere representation which presents a kind of external similitude, and so invites definition or decoding, while a symbol enjoys an internal and unfinished relationship with its referent, a real ontological correspondence that makes it to be what it is, and at the same time, to be a symbol (Borella 1989). As Paul Ricoeur writes:

The manifestation through the [symbol] thing is like the condensation of an infinite discourse; manifestation and meaning are strictly contemporaneous and reciprocal; the concretion in the thing is the counterpart of the surcharge of inexhaustible meaning which has ramifications in the cosmic, in the ethical, and in the political. Thus the symbol-thing is the potentiality of innumerable spoken symbols which, on the other hand, are knotted together in a single cosmic manifestation. ${ }^{7}$ (Ricœur 1967, p. 11)

Accordingly, symbols invite contemplation more than definition. Modern theories of the symbol have tended to aestheticize them, holding that symbols signify, to be sure, but also that they signify nothing beyond immanent human experience. This is often taken to be a consequence of their social construction: if we immanent beings make symbols, then surely the symbols can, at best, signify us. At this point a theory of projection is still sadly in league with the pathetic fallacy. We encountered a similar logic above in Žižek and Morton, albeit with Lacanian and Derridean or object-oriented spins respectively, but for Hugh, the symbol of nature was discovered more than invented, received more than made. Thus, the contemplation the symbol evoked was not limited to a human horizon. Morton, in getting rid of nature, would seem to get rid of all normativity in the name of human species-modesty. But following Hugh of Saint Victor's example, in the name of nature as Creation, we are able to sustain human dignity in a measured way, while encouraging a real vulnerability towards a nature that is all the more normative insofar as we are forever having to relearn its subtle and complex standards-a nature saturated with meaning beyond our human limits. ${ }^{8}$

Is this merely a regression to the erroneous premodern belief in a seamless fabric of nature and culture? Surely not, and this for two reasons. First, as Latour argues, the putative error only appears as such in light of the modern project decisively to separate nature and culture, a project that has always betrayed itself by covertly appealing to hybrids of all sorts, as is especially evident today with the advent of the Anthropocene. Moreover, one might argue, in the second place, that the premodern error lies not as modernity pretended in the conflation of nature and culture, but rather in the insistence that nature (and thus the ideals of culture) be timeless and necessary, somehow given apart from the

7 Appropriately, the context for Ricoeur's comment is his discussion of the symbols of nature. The entire passage reads: "First of all, then, it is the sun, the moon, the waters - that is to say, cosmic realities-that are symbols. Shall we say, therefore, that symbols, in their cosmic aspect, are interior to language, or even foreign to it? Not at all. For these realities to be a symbol is to gather together at one point a mass of significations which, before giving rise to thought, give rise to speech. The symbolic manifestation as a thing is a matrix of symbolic meanings as words. We have never ceased to find meanings in the sky... It is the same thing to say that the sky manifests the sacred and to say that it signifies the most high, the elevated and the immense, the powerful and the orderly, the clairvoyant and the wise, the sovereign, the immutable. The manifestation through the [symbol] thing is like the condensation of an infinite discourse; manifestation and meaning are strictly contemporaneous and reciprocal; the concretion in the thing is the counterpart of the surcharge of inexhaustible meaning which has ramifications in the cosmic, in the ethical, and in the political. Thus the symbol-thing is the potentiality of innumerable spoken symbols which, on the other hand, are knotted together in a single cosmic manifestation" (Ricœur 1967, p. 11).

8 In fact, a genealogy can be traced from the medieval contemplative liber naturae through to Romantic retrievals of the trope of the book of nature against its modern reduction to mathematics. The whole story has yet to be told, but key elements of it can be found in Brett Grainger's recent work (Grainger 2019, pp. 61-104). 
contingencies of history and becoming. This is what produces ideological appeals to nature, in that nature becomes a shortcut around politics, history, negotiation, and interpretation. But nature is not simply given, necessary, and therefore something to be passively received. Nature is not the stable backdrop for human activity and drama, but a dynamic participant in the drama of creation, of which we are all a part. This, perhaps, is something the twelfth-century Victorines could not yet know, but it is also something about which early modern philosophers were equally ignorant. The nineteenth century discovery of nature's vast history, and the new sense of our evolutionary and cultural historicity, undoubtedly transforms our reading of the book of nature. The book of nature is written in a living script. Arguably, however, the discovery of deep time more easily comports with Hugh of Saint Victor's refusal of any ultimate distinction between nature and culture than it does with modernity's characteristic bifurcation of the two. Beyond, but not against, what the premodern Hugh of Saint Victor knew, we might argue in postmodern fashion that if our creative symbol-making capacities are not merely expressions of transcendental human freedom, but rather if our creative and historical capacities are received like gifts, because we too are part of nature, we can in principle reconcile the opposition of active creation and passive reception without returning either to the modern illusion of a merely 'given' factual nature or to the demoralizing skepticism of thoroughgoing nominalism which assumes a purely 'willed' culture somehow outside and beyond nature.

Much more needs to be said in order to do justice to this argument, but we have at least established the possibility of a theological invocation of nature that escapes the now-problematic bifurcations of modernity, on the one hand, and the essentializing reifications of premodernity, on the other. By contrast, in accord with a more terrestrial hermeneutics of the book of nature, nature is neither a fantasy object to be ignored or fled, nor a stable text to be tamed, rationalized, and epistemically leveraged. Read theologically and Christologically, a creative retrieval of the book of nature is neither an exercise in nostalgia nor anachronism, for nature is not merely given, either for exploitation or sentiment. Rather, nature and the moral stances that nature empowers are able to remain without falling prey to the unravelling of recent critical theory. But nature remains precisely by relinquishing the pretensions to certainty and the immunity to history that so attracted her modern devotees. Instead, the changing concept and experience of nature is a symbol illuminated in a book we half receive and half create, a symbol open to both critique and contemplation, which gives rise to thought, action, and the sort of novel moral intuitions we need now more than ever.

Funding: This research received no external funding.

Conflicts of Interest: The author declares no conflict of interest.

\section{References}

Albertson, David, and Cabell King. 2010. Without Nature?: A New Condition for Theology, 1st ed. New York: Fordham University Press.

Angelici, Ruben. 2020. Semiotic Theory and Sacramentality in Hugh of Saint Victor, Contemporary Theological Explorations in Mysticism. Oxford and New York: Routledge.

Arendt, Hannah. 1998. The Human Condition, 2nd ed. Chicago: University of Chicago Press.

Bishop, Jeffrey Paul. 2011. The Anticipatory Corpse: Medicine, Power, and the Care of the Dying, Notre Dame Studies in Medical Ethics. Notre Dame: University of Notre Dame Press.

Borella, Jean. 1989. Le Mystère du Signe: Histoire et Théorie du Symbole, Collection Métalangage. Paris: Maisonneuve \& Larose.

Chenu, Marie Dominique. 1997. Nature, Man, and Society in the Twelfth Century: Essays on New Theological Perspectives in the Latin West. Translated by Jeremy Taylor, and Lester K. Little. Toronto: University of Toronto Press. First published 1957.

Cizewski, Wanda. 1987. Reading the World as Scripture: Hugh of St Victor's De Tribus Diebus. Florilegium 9: 65-88.

Clark, Timothy. 2011. The Cambridge Introduction to Literature and the Environment, Cambridge Introductions to Literature. Cambridge and New York: Cambridge University Press. 
Collingwood, Robin George. 1945. The Idea of Nature. London: Oxford University Press.

Coolman, Boyd Taylor. 2010. The Theology of Hugh of St. Victor: An Interpretation. New York: Cambridge University Press.

Coolman, Boyd Taylor, and Dale M. Coulter, eds. 2010. Trinity and Creation: A Selection of Works of Hugh, Richard and Adam of St Victor, Victorine Texts in Translation. Turnhout: Brepols.

Crutzen, Paul J. 2006. The "Anthropocene". In Earth System Science in the Anthropocene. Edited by Eckart Ehlers and Thomas Krafft. Berlin/Heidelberg: Springer, pp. 13-18.

Deane-Drummond, Celia, Sigurd Bergmann, and Markus Vogt, eds. 2017. Religion in the Anthropocene. Eugene: Cascade Books.

Evernden, Lorne Leslie Neil. 1992. The Social Creation of Nature. Baltimore: Johns Hopkins University Press.

Falque, Emmanuel. 2017. The Hidden Source of Hermeneutics: The Art of Reading in Hugh of St. Victor. Journal of French and Francophone Philosophy 25: 121-31. [CrossRef]

Galilei, Galileo, and Stillman Drake. 1990. Discoveries and Opinions of Galileo: Including The Starry Messenger (1610), Letter to the Grand Duchess Christina (1615), and Excerpts from Letters on Sunspots (1613), The Assayer (1623). New York: Anchor Books.

Gersdorf, Catrin, and Sylvia Mayer. 2006. Nature in Literary and Cultural Studies: Transatlantic Conversations on Ecocriticism, Nature, Culture and Literature. Amsterdam and New York: Rodopi.

Grainger, Brett. 2019. Church in the Wild: Evangelicals in Antebellum America. Cambridge: Harvard University Press.

Grebowicz, Margret, Helen Merrick, and Donna Jeanne Haraway. 2013. Beyond the Cyborg: Adventures with Donna Haraway. New York: Columbia University Press.

Hadot, Pierre. 2006. The Veil of Isis: An Essay on the History of the Idea of Nature. Translated by Michael Chase. Cambridge: Harvard University Press.

Hamilton, Clive, Christophe Bonneuil, and François Gemenne. 2015. The Anthropocene and the Global Environmental Crisis. London and New York: Routledge.

Haraway, Donna Jeanne. 2016a. Manifestly Haraway, Posthumanities. Minneapolis: University of Minnesota Press.

Haraway, Donna Jeanne. 2016b. Staying with the Trouble: Making Kin in the Chthulucene, Experimental Futures: Technological Lives, Scientific Arts, Anthropological Voices. Durham: Duke University Press.

Harman, Graham. 2009. Prince of Networks: Bruno Latour and Metaphysics, Anamnesis. Melbourne: Re.press.

Harrison, Peter. 2015. The Territories of Science and Religion. Chicago: The University of Chicago Press.

Hugh of Saint-Victor. 1991. Didascalicon: A Medieval Guide to the Arts. New York: Columbia University Press.

Hugh of Saint-Victor. 2007. On the Sacraments of the Christian Faith: (De Sacramentis). Eugene: Wipf \& Stock Publishers.

Illich, Ivan. 1993. In the Vineyard of the Text: A Commentary to Hugh's Didascalicon. Chicago: University of Chicago Press.

Kaufman, Gordon D. 1972. A Problem for Theology: The Concept of Nature. Harvard Theological Review 65: 337-66. [CrossRef]

Latour, Bruno. 1993. We Have Never Been Modern. Cambridge: Harvard University Press.

Latour, Bruno. 2004. Politics of Nature: How to Bring the Sciences into Democracy. Cambridge: Harvard University Press.

Latour, Bruno. 2018. Down to Earth: Politics in the New Climatic Regime. English ed. Cambridge and Medford: Polity.

Lewis, Clive Staples. 1960. Nature (with Phusis, Kind, Physical, etc.). In Studies in Words. Cambridge: University Press, pp. 24-74.

Lewis, Clive Staples. 2001. The Abolition of Man, or, Reflections on Education with Special Reference to the Teaching of English in the Upper Forms of Schools. San Francisco: HarperSanFrancisco.

Lewis, Simon L., and Mark Maslin. 2018. The Human Planet: How we Created the Anthropocene. New Haven and London: Yale University Press.

McGrath, Alister E. 2001. A Scientific Theology: Nature. Grand Rapids: Eerdmans Pub. Co., vol. 1.

Morton, Timothy. 2007. Ecology without Nature: Rethinking Environmental Aesthetics. Cambridge: Harvard University Press.

Morton, Timothy. 2013a. Realist magic: Objects, ontology, causality. In New Metaphysics. Ann Arbor: Open Humanities Press.

Morton, TImothy. 2013b. X-ray. In Prismatic Ecology: Ecotheory beyond Green. Edited by Jeffrey Jerome Cohen. Minneapolis: University of Minnesota Press, pp. 311-27.

Morton, Timothy. 2018. Being Ecological. Cambridge: The MIT Press.

Ricœur, Paul. 1967. The Symbolism of Evil. In Religious Perspectives, 1st ed. New York: Harper \& Row. 
Rolston, Holmes. 1986. Philosophy Gone Wild: Essays in Environmental Ethics. Buffalo: Prometheus Books.

Rolston, Holmes. 1997. Nature for Real: Is Nature a Social Construct. In The Philosophy of the Environment. Edited by Timothy D. J. Chappell. Edinburgh: University of Edinburgh Press, pp. 38-64.

Stengers, Isabelle. 2010. Cosmopolitics. In Posthumanities. 2 vols. Minneapolis: University of Minnesota Press.

Taylor, Charles. 1989. Sources of the Self: The Making of the Modern Identity. Cambridge: Harvard University Press. Whitehead, Alfred North. 2015. The Concept of Nature: The Tarner Lectures Delivered in Trinity College, November 1919. Cambridge Philosophy Classics ed. Cambridge: Cambridge University Press.

Williams, Raymond. 1980. Ideas of nature. In Problems in Materialism and Culture: Selected Essays. London: Verso, pp. 67-85.

Williams, Raymond. 2014. Nature. In Keywords: A Vocabulary of Culture and Society. Oxford and New York: Oxford University Press, pp. 164-70.

Wolterstorff, Nicholas. 2010. The MIgration of Theistic Arguments from natural theology to evidentialist apologetics. In Practices of Belief: Selected Essays. Cambridge and New York: Cambridge University Press, pp. 173-216.

Žižek, Slavoj. 2008a. In Defense of Lost Causes. London: Verso.

Žižek, Slavoj. 2008b. Nature and Its Discontents. SubStance 37: 37-72. [CrossRef]

(C) 2020 by the author. Licensee MDPI, Basel, Switzerland. This article is an open access article distributed under the terms and conditions of the Creative Commons Attribution (CC BY) license (http://creativecommons.org/licenses/by/4.0/). 